\title{
PENGARUH PAJAK KENDARAAN BERMOTOR TARIF PROGRESIF DAN PENDAPATAN WAJIB PAJAK TERHADAP DAYA BELI KONSUMEN KENDARAAN BERMOTOR RODA EMPAT (Studi Empiris Di Kantor SAMSAT Kota Jayapura)
}

\author{
Marice Waroi ${ }^{1}$ \\ maricewaroii@gmail.com \\ Aaron M. A. Simanjuntak, SE., M.Si., CBV., CMA ${ }^{2}$ \\ Hastutie Noor Andriati, SE., M.Si., Ak., $\mathbf{C A}^{3}$ \\ Jurusan Akuntansi, Fakultas Ekonomi dan Bisnis Universitas Cenderawasih
}

\begin{abstract}
This study aims to determine the Effect of Progressive Vehicle Taxes and Taxpayer Income on Consumer Purchasing Power. The research population is taxpayers who make motor vehicle tax payments in the Jayapura City Samsat Office. The number of samples is 70 people. Determination of the study sample using the nonprobability sampling method, data was collected by distributing questionnaires. The data analysis technique is multiple linear analysis. The results of the research conducted show that Progressive Vehicle Taxes have no significant positive effect on Consumer Purchasing Power, Taxpayer Income does not have a significant negative effect on Consumer Purchasing Power. The most dominant variable affects taxpayers regarding the tax on progressive tariff motor vehicles because they have a standard coefficient of beta 0235.
\end{abstract}

Keywords : :Motor Vehicle Tax, Taxpayer income, Purchasing Power.

\section{PENDAHULUAN}

Indonesia merupakan negara yang yang sementara berkembang saat ini terus menerus melaksanakan pembangunan disegala bidang baik itu di bidang sosial, politik, hukum, pendidikan, dan juga ekonomi. Tujuan dari pembangunan tersebut salah satunya yaitu untuk kesejahteran rakyat Pemerintah Indonesia dalam melakukan pembiayaan pembangunan dilakukan dalam mewujudkan tujuan dari suatu pembangunan dilakukan dalam tiga sektor yaitu sektor pajak, sektor migas, dan sektor bukan pajak. Usaha yang harus ditempuh pemerintah untuk mendapatkan pembiayaan ialah salah satunya dengan meningkatkan potensi pendapatan yang berasal dari negara Indonesia sendiri yang berasal dari pajak.Fadillah \& Kiswara (2012)pajak merupakan kewajiban kepada negara (yang dapat dipaksakan) yang dikatan berutang diharuskan wajib membayarnya menurut peraturanperaturan, tanpa mendapat prestasi kembali, yang langsung dapat ditunjuk, dan gunanya adalah untuk pembiayaan pengeluaran-pengeluaran umum terhadap tugas Negara sebagai penyelenggaraan.

Bahwa ditetapkannya Peraturan Gubernur Provinsi Papua Nomor 5 Tahun 2010 tentang Pembentukan, Susunan Organisasi dan tata kerja Unit Pelaksana Teknis pada Dinas-Dinas Daerah Provinsi Papua, dan sesuai perkembangan keadaan perlu meninjau kembali Peraturan Daerah Provinsi Papua Nomor 20 Tahun 2006 tentang Pembentukan Kantor Bersama Sistem Administrasi Manuggal Di Bawah Satu Atap (SAMSAT) se Provinsi Papua. Bahwa dengan diundangkannya Undang-undang Nomor 28 Tahun 2009 tentang Pajak Daerah Tahun 1998 tentang Pajak Bahan Bakar Kendaraan Bermotor, Peraturan Daerah Provinsi Papua Nomor 6 Tahun 2002 tentang Pajak Kendaraan Bermotor.

Pajak kendaraan bermotor memiliki peranan penting bagi pendapatan daerah karena memberikan kontribusi yang cukup besar. Pajak selain sebagai sumber pendapatan negara juga berfungsi sebagai

\footnotetext{
${ }^{1}$ Alumni Jurusan Akuntansi FEB Uncen

${ }^{2}$ Dosen Jurusan Akuntansi FEB Uncen

3 Dosen Jurusan Akuntansi FEB Uncen
} 
distribusi pemerataaan pendapatan. Pajak penghasilan orang pribadi merupakan salah satu instrumen dalam rangka mengatasi kesenjangan pemerataan distribusi pendapatan antara orang yang memiliki penghasilan tinggi dan yang memiliki penghasilan rendah. Tarif pajak penghasilan orang pribadi di Indonesia mengenal tarif pajak progresif dimana semakin tinggi penghasilan akan semakin tinggi pula tarif pajak penghasilannya.

Pajak progresif ialah pajak yang sistem pemungutannya dengan cara menaikan presentase kena pajak yang harus dibayar sesuai dengan kenaikan objek pajak. Dalam sistem perpajakan di indonesia, terdapat dua jenis pajak kendaraan bermotor.

Jumlah kendaraan bermotor di Kota Jayapura yaitu 110.558 unit dari tahun 2014-2018 (Kantor Samsat Jayapura) bertambah jumlah kendaraan di jalan Kota Jayapura satu sisi pendapatan Pajak Daerah Kota Jaayapura akan ikut meningkat. Tahun 2014 hingga tahun 2018 jumlah kendaraan bermotor roda empat dapat dilihat di Tabel 1 berikut ini :

\section{Tabel 1}

\section{Jumlah Kendaran Roda Empat di Kota Jayapura Tahun 2014-2018}

\begin{tabular}{|c|c|}
\hline Tahun & Jumlah (unit) \\
\hline 2014 & 19.730 \\
2015 & 20.939 \\
2016 & 22.262 \\
2017 & 23.332 \\
2018 & 24.295 \\
\hline
\end{tabular}

Sumber : Kantor Samsat Kota Jayapura

Khususnya pajak kendaraan bermotor yang dikenakan pada kendaraan roda empat milik pribadi menimbulkan meningkatnya jumlah kendaraan bermotor memberikan dampak kemacetan lalu lintas yang hampir terjadi di setiap jalan besar di Kota Jayapura. Dinas Pendapatan Daerah Provinsi Papua terhitung mulai 05 Januari 2015 menerapkan tarif Pajak Progresif. Wajib pajak yang memilik kendaraan yang lebih dari satu, kendaraan kedua dan seterusnya dikenakan tarif pajak progresif 2 persen sampai dengan 3,5 persen tergantung urutan kepemilikan. Pajak progresif hanya di berlakukan untuk kendaraan pribadi roda empat dengan kepemilikan didasarkan atas nama dan/atau alamat yang sama.

Selain dipengaruh oleh harga jual, daya beli juga dipengaruhi oleh jumlah pendapatan masyarakat. Pendapatan merupakan sejumlah penghasilan yang diperoleh anggota masyarakat dalam periode waktu tertentu sebagai balas atau faktor-faktor produksi yang telah diberikan Danil(2013). Tingkat pendapatan seseorang mencerminkan daya belinya terhadap suatu barang. Semakin meningkat suatu pendapatan, maka masyarakat akan membeli lebih banyak dibandingkan sebelum pendapatannya meningkat Utami(2006). Dengan adanya pendapatan yang tinggi, masyarakat tidak akankeberatan mengenai harga jual barang, untuk hal ini harga jual kendaraan bermotor. Masyarakat akan tetap membeli kendaraan bermotor walaupun terjadi peningkatan jumlah beban pajak yang dikenakan karena masyarakat masih mampu untuk membayar beban pajak tersebut (Chaerannisah, 2014).

Penelitian yang dilakukan Adiputri \& Jati(2018) Pengaruh Pajak Kendaraan Bermotor Tarif Progresif dan Pendapatan Wajib Pajak Terhadap Daya Beli Kendaran Bermotor Roda Empat. Hasil penelitian tersebut menunjukan bahwa pajak kendaraan bermotor tarif progresif berpengaruh negatif terhadap daya beli konsumen kendaraan bermotor roda empat milik pribadi dan pendapatan wajib berpengaruh positif terhadapat daya beli kendaraan bermotor roda empat milik pribadi di Kota Denpasar. Rumusan masalah penelitian ini ialah Apakah Pajak kendaraan bermotor tarif progresif dan pendapatan wajib pajak berpengaruh terhadap daya beli konsumen kendaraan bermotor roda empat 
milik pribadi di Kota Jayapura. Penelitian ini bertujuan untuk mengetahui dan menganalisis pengaruh pajak kendaraan bermotor tarif progresif dan pendapatan wajib pajak terhadap daya bel i konsumen kendaraan bermotor milik pribadi di Kota Jayapura.

\section{LANDASAN TEORI}

\subsection{Teori dan Konsep}

Teori asas daya beli dicetuskan oleh Prof. Dr.P.J.A.Adriani, fungsi pajak didalam masyarakat disamakan dengan pompa, yaitu menyedot atau mengambil daya beli dari rumah tangga masyarakat untuk rumah tangga negara, kemudian memberikan kembali ke masyarakat dengan maksud untuk memilihara kehidupan masyarakat dan menyejahterakan masyarakat. Teori ini menjelaskan bahwa kepentingan masyarakat inilah yang mampu dijadikan sebagai dasar keadilan pemungutan pajak bukan untuk kepentingan lainnya, melainkan kepentingan masyarakat. Maka dapat disimpulkan bahwa teori menitik beratkan ajarnya pada fungsi pajak sebagai pengatur (regulerend). Adapun teori asas daya beli berhubungan dengan kemampuan masyarakat dalam bertransaksi dengan pihak lain. Pajak yang berhubungan dengan transaksi ini dikenal dengan pajak kendaraan bermotor Mardiasmo (2011).

Suatu rasa hormat atau berwibawa yang di peroleh seseorang karena keahliannya di segala macam bidang (seperti kekayaan atau suatu barang prestise) sehingga kemudian menyebabkannya menjadi lain atau luar biasa jika dilihat dari masyarakat-masyarakat yang ada dilingkungan sekitarnya disebut prestise Mariska febe (2015). Memiliki kendaraan bermotor roda empat suda pasti dapat meningkatkan rasa prestise dari pemilik kendaraan tersebut. Semakin banyak dan semakin mewah kendaraan bermotor roda empatnya, tentu saja akan meningkatkan beban pajak yang dikenakan, khusus pajak kendaraan bermotor Claudya (2015).

"Menurut Prof. Dr. PJA Andriani pajak adalah iuran atau pungutan masyarakat kepada negara yang dapat untuk di paksakan serta akan terhutang bagi yang wajib membayarnya yang sesuai dengan tidak dapat memperoleh imbalan yang langsung bisa ditunjuk dan dipakai dalam pembiayaan yang diperlukan negara."

"Menurut Prof Dr.M.H.J Smeets pajak adalah prestasi pemerintah yang terutang melalui normanorma umum dan yang dapat dipaksakan, tanpa ada kontraprestasi yang dapat ditunjukan secara individual. maksudnya adalah untuk membiayai pengeluaran pemerintah."

Menurut Nababan (2013), pendapatan merupakan seruluh total hasil yang diperoleh atau diterima dalam suatu periode. Pendapatan wajib pajak akan berpengaruh terhadap barang yang digunakan, bahkan sering sekali didapatkan bahwa apabila pendapatan seorang bertambah, maka barang yang digunakan tidak hanya bertambah, tetapi kualitas dari barang tersebut akan menjadi perhatian Lapodo \& Sulaeman(2016). Tingkat mendapatan daya beli. Semakin tinggi suatu pendapatan seseorang wajib pajak, maka kemampuan daya beli akan semakin kuat, sehingga jumlah permintaan kendaraan bermotor ikut meningkat juga.

Dalam pengertian umum pendapatan ialah hasil pencarian usaha. Pendapatan wajib pajak merupakan jumlah penghasilan Rupiah yang dihasilkan wajib pajak yang diperoleh dari pekerjaan utama maupun sampingan Imtikhanah dan Susiltoyowati (2010). Sedangkan menurut Rahman (2018) pendapatan keluarga ialah segala balas karya yang diperoleh sebagai imbalan atau balas jasa atas sumbagan seseorang terhadap proses produksi. Berdasarkan definisi singkatan diatas, maka dapat diambil kesimpulan bahwapendapatan ialah semua penghasilan yang diterima oleh orang berupa uang atau barang sebagai balas jasa dari faktor-faktor produksi.

Daya beli konsumen merupakan kemampuan seorang untuk membeli suatu barang atau jasa, Menurut Fadillah \& Kiswara (2012)daya beli (purchasing power) merupakan kemampuan seseorang dalam mengkonsumsi suatu produk. Daya beli orang dengan yang lain tentu saja berbeda. Hal ini disebabkan oleh beberapa faktor, seperti jumlah pendapat seseorang, status sosial seseorang, pekerjaan, dan lainnya. 
Menurut (Soediyono Reksoprayitno, 2007)terdapat 4 (empat) penyebab perubahan permintaan, yaitu:

1. Perubahan pendapat konsumen

2. Perubahan harga barang penganti

3. Perubahan cita rasa konsumen

\subsection{Penelitian Terdahulu dan Pengembangan Hipotesis}

Berdasarkan penelitian terdahulu akan diuraikan secara ringkas karena penelitian ini mengacu pada pada beberapa penelitian sebelumnya. Pengujian yang diteliti oleh Murthi, Buhdi, \& Purbadharmaja(2015)mengatakan pengenaan Pajak Kendaraan Bermotor dengan tarif progresif mempunyai pengaruh positif terhadap daya beli masyarakat. Namun, hasil pengujian yang diteliti oleh Ratnasari \& Setiawan(2016) dan Devi (2017)mengenai pengenaan Pajak Kendaraan Bermotor terhadap daya beli konsumen memperlihatkan hasil ialah Pajak Kendaraan Bermotor mempunyai pengaruh `negatif pada daya beli konsumen. Peningkatnya beban pajak akan menurunkan daya beli konsumen Ratnasari(2015). Pengenaan tarif progresif dalam Pajak Kendaraan Bermotor akan mengakibatkan pemilik kendaraan terkena terkena pajak lebih tinggi untuk pembayaran pajak pajak kendaraan kedua dan selanjutnya sehingga daya beli masyarakat pada kendaraan bermotor akan menurun, terutama kendaraan bermotor roda empat Ermawati \& Widiastuti(2014).

Penelitian sebelumnya yang dilakukan oleh Ridwan(2012)menunjukan bahwa pendapatan berpengaruh positif terhadap daya beli. Diperkuat dengan penelitian yang dilakukan oleh Chaerannisah(2014) dan Hetriana (2015) yang menyatakan pendapatan berpengaruh positif signifikan terhadap daya beli. Pengujian yang diteliti oleh Ratnasari(2015) dan Devi (2017) mengenai pengenaan pajak kendaraan bermotor terhadap daya beli konsumen memperlihatkan hasil yaitu pajak kendaraan bermotor mempunyai pengaruh negatif pada daya beli konsumen. Peningkatan beban pajak akan menurunkan daya beli konsumen Ratnasari(2015).

Pengenaan tarif progresif dalam pajak kendaraan bermotor akan mengakibatkan pemilik kendaraan terkena pajak lebih tinggi untuk pembayaran pajak kendaraan yang kedua dan selanjutnya sehingga daya beli masyaraka pada kendaraan bermotorakan menurun, terutama kendaraan bermotor roda empat Ermawati \& Widiastuti(2014).

Berdasarkan uraian tersebut maka dapat dirumuskan hipotesis penilitian sebagai berikut:

$\mathrm{H}_{1}$ : Pajak Kendaraan Bermotor Tarif Progresif berpengaruh negatif terhadap daya beli

konsumen kendaraan bermotor roda empat milik pribadi.

Setiap wajib pajak memiliki karakteristik dan kondisi yang berbeda beda termasuk mengenai kondisi kemampuan keuangan. Kemampuan ekonomi seorang wajib pajak dapat dipresentasikan dengan jumlah kendaraan yang dimilikinya Irwanto (2015). Jika pendapata masyarakat tinggi, maka konsumsi akan meningkat, tanpa memperhatikan beberapa besar pajak yang dikenakan Hetriana(2015).

Penelitian sebelumnya yang dilakukan oleh Ridwan (2012) menunjukan bahwa pendapatan berpengaruh positif terhadap daya beli. Diperkuat dengan penelitian yang dilakukan oleh Chaerannisah (2014) dan Hetriana (2015) yang menyatakan pendapatan berpengaruh positif signifikan terhadap daya beli.

Berdasarkan uraian tersebut maka dapat dirumukan hipotesis penelitian sebagai berikut:

$\mathrm{H}_{2}$ : Pendapatan Wajib Pajak berpengaruh positif terhadap daya beli konsumen kendaraan bermotor roda empat milik pribadi. 


\subsection{Model Penelitian}

Dari kajian teori dan peneltian terdahu terdahulu diatas, maka dapa dibuat model penelitian sebagai berikut :

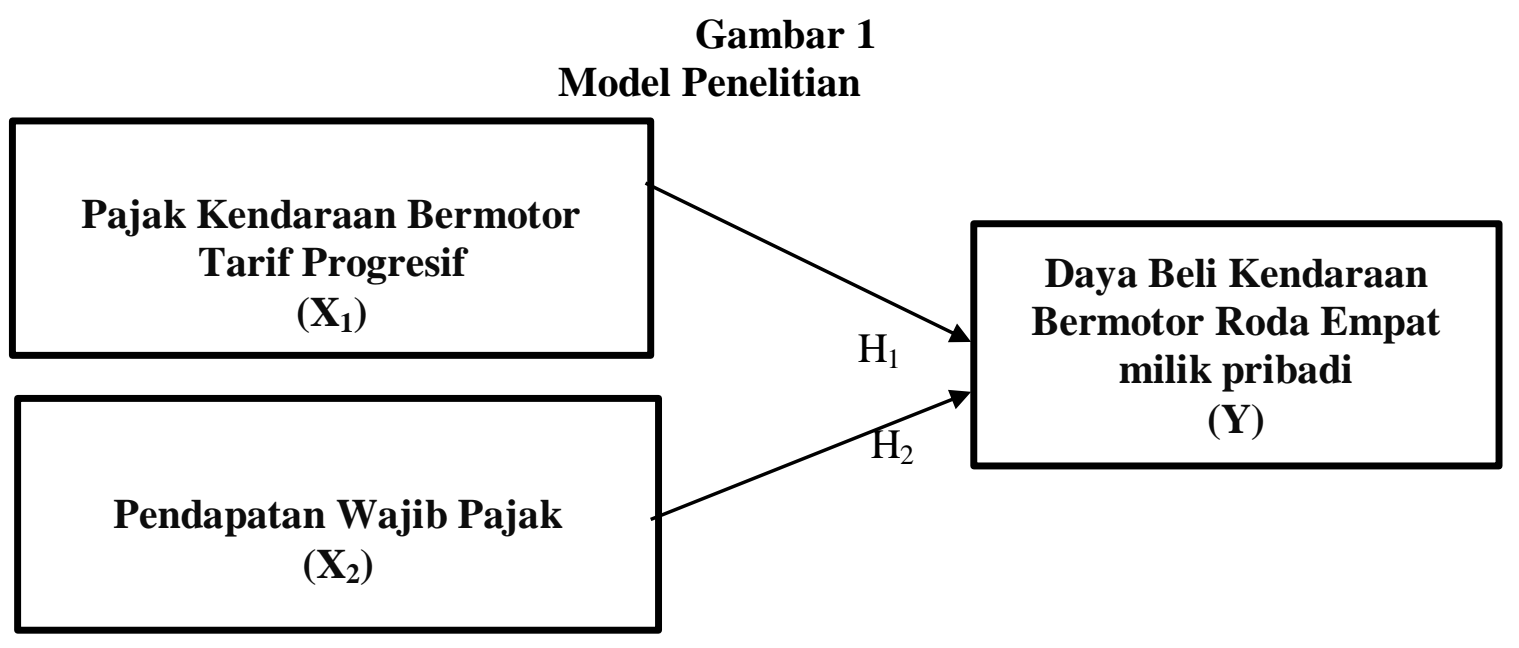

Sumber : Penelitian 2019

\section{METODE PENELITIAN}

\subsection{Jenis Penelitian}

Penelitian ini menggunakan pendekatan kuantitatif berbentuk penelitian asosiatif dengan hubungan kausal.

\subsection{Lokasi dan Objek Penelitian}

Lokasi penelitian ini dilakukan dikantor SAMSAT Kota Jayapura. Alasan dilakukan penelitian di kantor SAMSAT kota Jayapura, karena kantor ini merupakan institusi yang memilliki wewenang untuk memungut pajak kendaraan bermotor Pemda tingkat I, dan sering dijumpai permasalahan terkait pajak kendaraan bermotor seperti masih kurangnya pemahaman wajib pajak megenai penyebab terjadinya peningkatan beban beban pajak yang dibayarkan. Menjadi objek penelitian ini ialah daya beli konsumen kendaraan bermotor roda empat milik pribadi di Kota Jayapura.

\subsection{Populasi dan Sampel}

Populasi dalam penelitian ini ialah seluhruh wajib pajak yang melakukan pembayaran pajak di kantor SAMSAT Kota Jayapura. Metode penentuan sampel pada penelitian ini adalah non-probability sampling dengan teknik purposive sampling merupakan penentuan sampel dengan menggunakan pertimbangan pajak kendaraan bermotor roda empat lebih dari satu. Porposi sampelnya akan ditentukan menggunakan rumus Slovin Husein(2008). Jumlah sampel yang di peroleh dalam penelitian ini ialah 70 responden yang terdiri dari wajib pajak yang melakukan pembayaran pajak pada Kantor SAMSAT Kota Jayapura, dan terdistribusi di lima distrik Kota Jayapura dan terdistribusi 4 merk mobil dominan dipakai di Kota Jayapura.

$\mathrm{n}=\frac{\mathrm{N}}{\left(1+\mathrm{N} \cdot \mathrm{e}^{2}\right)}$

Keterangan :

$\mathrm{n} \quad=$ Jumlah sampel

$\mathrm{N}=$ Jumlah Populasi

$\mathrm{e}^{2}=$ Nilai kritis (batas ketelitian 0,5 ) 


\subsection{Jenis dan Sumber Data}

Jenis data dalam penilitian ini menggunakan data kuantitatif dan kualitatif. Data kuantitatif dalam penelitian ini ialah data pemilik kendaraan bermotor roda empat di Kota Jatyapura. Sedangkan data kualitatif yaitu terdiri dari pendapatan responden terhadap pernyataan yang meliputi dampak dari pengenaan Pajak Kendaraan Bermotor tarif progresif (mobil) serta kemampuan pendapatan wajib pajak untuk pembeli kendaraan bermotor roda empat. Data primer dan sekunder merupakan sumber data yang digunakan dalam penelitian ini. Data primer yang digunakan ialah jawaban dari responden terhadap kuisioner yang telah diberikan. Data sekunder dalam ini terdiri dari data pemilik kendaraan bermotor empat di Kota Jayapura.

\subsection{Variabel Penelitian dan Definisi Operasional}

Tabel 2

Variabel Penelitian dan Indikator Penelitian

\begin{tabular}{|c|c|c|c|c|}
\hline Mo & Tarizbel & Definis Vuriabs & Intil:ator & $\begin{array}{c}\text { Si:nla } \\
\text { Fengul: } \\
\text { w:n }\end{array}$ \\
\hline \multicolumn{5}{|c|}{ 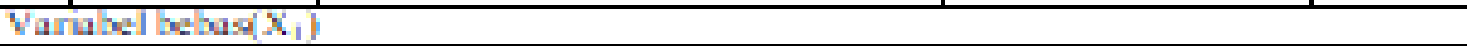 } \\
\hline II & 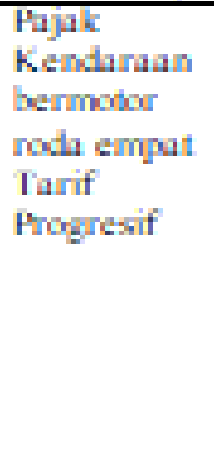 & 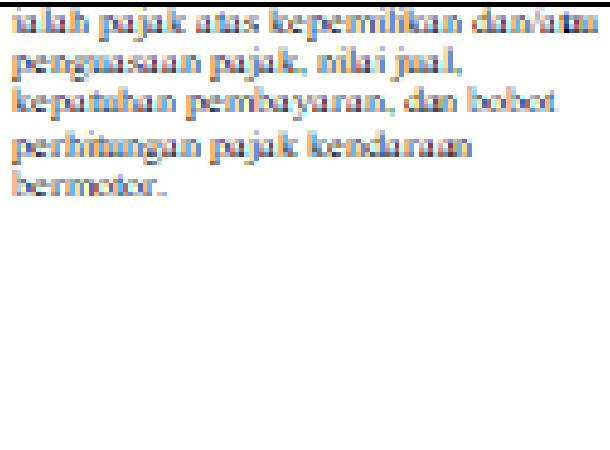 & 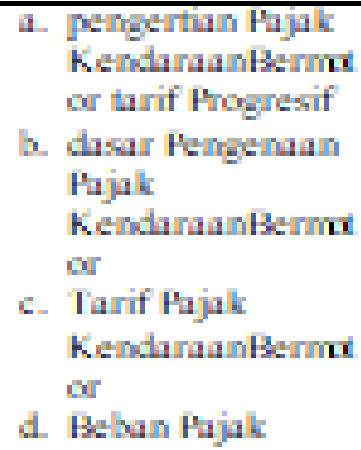 & Thating \\
\hline \multicolumn{5}{|c|}{ Maristidn } \\
\hline 2 & 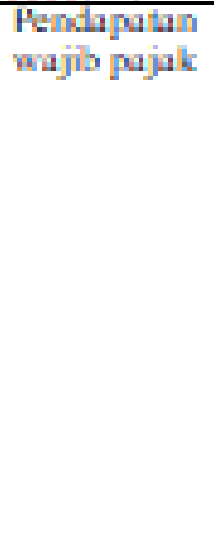 & 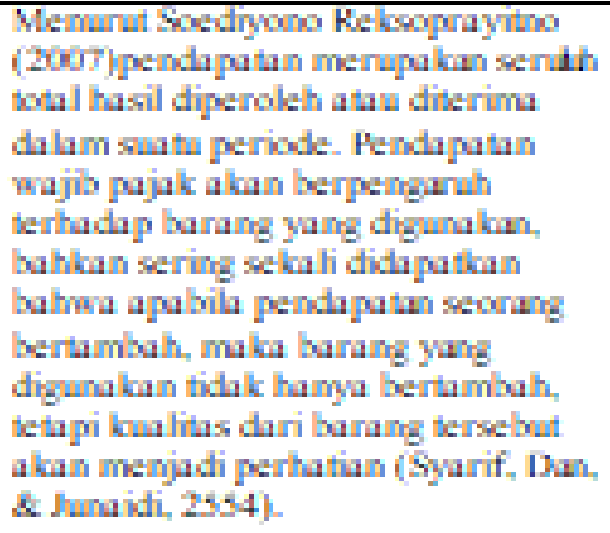 & 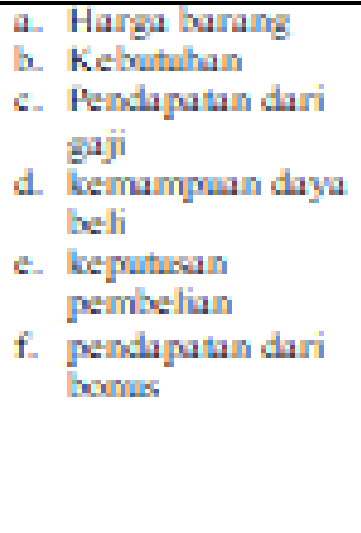 & Thiting \\
\hline \multicolumn{5}{|c|}{ 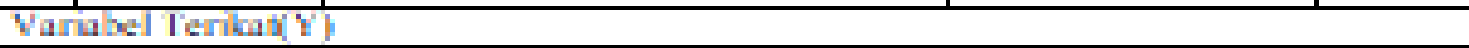 } \\
\hline 3 & $\begin{array}{l}\text { Thay Pali } \\
\text { Konemmein }\end{array}$ & 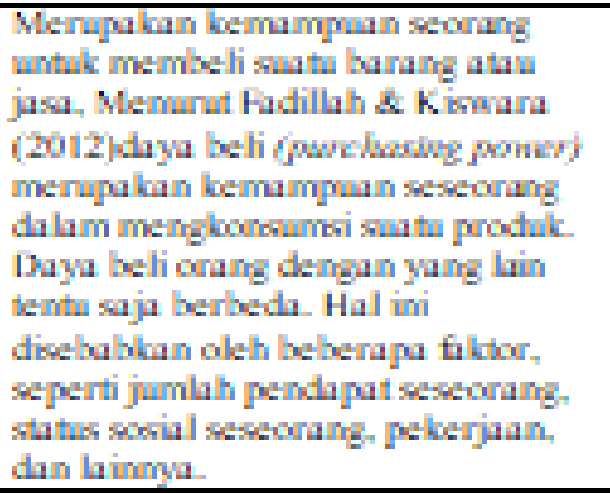 & 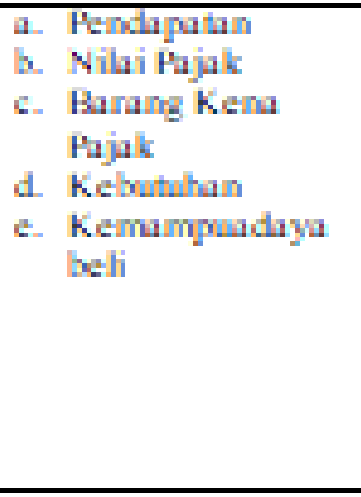 & Thation \\
\hline
\end{tabular}




\subsection{Teknik Pengumpulan Data}

Metode pengumpulan data yang digunakan dalam penelitian ini ialah metode vasiobservasi nonpratisipan dan metode kuisioner. Metode observasi nonpartisipan yaitu pengummpulan data yang dilakukan dengan cara membaca, mengamati, mencatat dan mempelajari uraian-uraian dari buku, karya ilmiah berupa skripsi, dan jurnal-jurnal akuntansi, yang berhubungan dengan topikyang dibahas dalam penelitian ini. Data yang dipakai dalam penelitian ini bersumber dari data kepemilikan kendaraan bermotor roda empat milik pribadi di Kota Jayapura. Kuisioner penelitian ini diberikan kepada respoden yaitu konsumen kendaraan bermotor roda empat milik pribadi di Kota Jayapura. Hasil dari kuisioner diukur menggunakan skala likert dengan skala 5 point ialah, skor (1) Sangat Tidak Setuju (STS), (2) Tidak Setuju (TS), (3) Netral (N), (4) Setuju (S), dan skor (5) Sangat Setuju (SS).

\subsection{Analisis Regresi Linear Berganda}

Analisis linier berganda yang diolah menggunakan apalikasi SPSS. Yaitu teknik analisis data yang digunakan dalam penelitian. Persamaan regresi untuk penelitian ini adalah sebagai berikut:

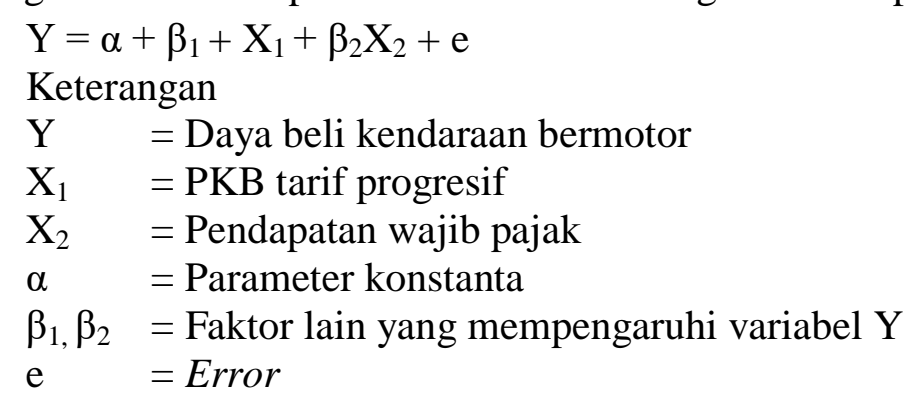

\subsection{Pengujian Hipotesis}

Uji kualitas data yang digunakan ialah uji validitas dan reliabilatas. Uji validasitas digunakan untuk menguji apakah pernyataan dalam kuisioner valid atau tidak. Uji reliabilitas bertujuan untuk beberapa besar variabel dalam penelitian dapat di percaya. Uji asumsi klasik yang digunakan dalam penelitian ini ialah uji normalitas, uji heteroskedasitas dan uji multikolinearitas.

Uji koefisien determinasi dilakukan untuk mengetahui seberapa besar variabel dependen mampu dijelaskan oleh variabel independennya, sedangkan sisanya dijelaskan oleh variabel lain diluar penelitian. Uji F digunakan untuk kelayakan model penelitian. Uji t digunakan untuk mengetahui apakah variabel independen secara parsial memiliki pengaruh yang signifikan terhadap variabel dependen.

\section{HASIL DAN PEMBAHASAN}

\subsection{Gambaran Umum Objek Penelitian}

Penelitian ini di kumpulkan melalui penyebaran kuisioner ke Kantor Samsat Kota Jayapura. Jumlah kuisioner 100 yang didistribusikan tetapi yang kembali hanya 70 kuisoner dan sisa 30 tidak di kembalikian dan yang dapat diolah hanya 70 kuisioner. Responden dalam penelitian dibagi menjadi beberapa karakteristik responden yang terdiri dari jenis kelamin, usia, pekerjaan, pendapatan, jumlah kendaraan roda empat yang dimiliki, dan merek kendaraan yang dimiliki.berdasarkan 70 kuisioner, karakeristik responden berdasarkan jenis kelamin didominasi oleh responden yang berjenis kelamin lai-laki ialah sebesar 57,1\%. Kelompok usia paling tinggi ialah kelompok usia 39-45 tahun sebesar 45.7\%. kelompok pekerjaan yang paling tinggi ialah Pengawai Negeri Sipil (PNS) ialah sebesar 25,7\%. Kelompok pendapatan yang paling tinggi < 10 juta ialah sebesar 44,3\%. Kelompok jumlah kendaraan roda empat yang paling tinggi ialah 2 buah kendaraan sebesar 70,0 \%. Kelompok merk kendaraan yang paling tinggi ialah toyota sebesar 38,6\%. 


\subsection{Statistik Deskriptif}

Berikut ini akan diuraikan pengolaan data untuk menganalisis pengujian hipotesis pertama dan hipotesis kedua yang dijabarkan pada bagian sebelumnya dan memberikan uraian mengenai hasil pengolahan data yang diperoleh dalam penelitian ini akan diuraikan tentang hasil data yang diperoleh dalam penelitian ini.

Untuk menunjukan informasi karakteristik Variabel penelitian yang ditunjukkan pada banyak pengamatan, nilai minimum, nilai maksimum, nilai mean dan standar devisiasi Ghozali (2016:19). Tabel 3 menujukkan hasil uji statistik deskriptif.

Tabel 3

Hasil Uji Statistik Deskriptif

\begin{tabular}{|c|c|c|c|c|c|}
\hline Variabel & $\mathbf{N}$ & Min & Max & Mean & Std.Devisiasi \\
\hline Pajak Kendaraan & 70 & 14.00 & 20.00 & 18.4429 & 1.23518 \\
\hline Bermotor Tarif & & & & & \\
\hline Progresif (mobil) & & & & & \\
\hline$(\mathrm{X} 1)$ & 70 & 24.00 & 30.00 & 28.3571 & 1.10382 \\
\hline Pend.WP (X2) & 70 & 20.00 & 25.00 & 22.9143 & 1.16399 \\
\hline Daya Beli (Y) & 70 & & & & \\
\hline Valin N (listwise) & & & & & \\
\hline
\end{tabular}

Dari hasil pengujian statistik deskriptif dapat dinyatakan sebagai berikut :

A. Variabel Pajak Kendaraan Bermotor tarif Progresif (X1) dengan nilai minimum ialah 14.00, nilai maksimum ialah 20.00, mean 18.44 dan standar deviasi ialah 1.23. Hal ini menunjukan terdapat perbedaan nilai Pajak Kendaraan Bermotor tarif progresif yang di teliti dengan nilai rata-ratanya yaitu 1.23 .

B. Variabel Pendapatan Wajib Pajak (X2) menunjukan niai minimum senilai 24.00, nilai maksimum yaitu 30.00, mean sebesar 28,35dan standar deviasi yaitu 1,10. Ini berarti bahwa terdapat perbedaan nilai wajib pajak yang diteliti dengan nilai rata-rata yaitu 1.10.

C. Variabel Daya Beli (Y) mempunyai nilai minimum ialah 20.00, nilai maksimum ialah 25.00, mean sebesar 22.9 dan standar deviasi ialah 1.16. Hal ini menunjukan terdapat perbedaan nilai daya beli yang diteliti dengan dengan nilai rata-ratanya 1.16 .

\subsection{Uji Validitas dan Reliabilitas Data}

Uji Validitas dilakukan untuk mengetahui kelayakan butir-butir dalam suatu daftar pertanyaan dalam mendefinisikan suatu variabel. Daftar pertanyaan ini pada umunya mendukung suatu kelompok variabel tertentu. Dengan tingkat signifikan.

Tabel 4

Uji Validitas Pajak Kendaraan Bermotor Tarif Progresif (X1)

\begin{tabular}{|c|c|c|c|}
\hline Item & R hitung & R tabel & Keterangan \\
\hline 1 & 0.355 & 0.235 & Valid \\
2 & 0.406 & 0.235 & Valid \\
3 & 0.267 & 0.235 & Valid \\
4 & 0.328 & 0.235 & Valid \\
\hline
\end{tabular}

Sumber : Data Diolah 
Nilai ${ }^{\mathrm{r}}$ tabel untuk sampel taraf signifikasi 0.05 adalah 0.235 . Tabel 4 menunjukan bahwa semua butir pertanyaan tentang tentang Pajak Kendaraan Bermotor Tarif Progresif (mobil) (1-4) adalah valid. Karena nilai rtabel. Dengan demikian semua butir pertanyaan angket transparasi Pajak Kendaraan Bermotor Tarif Progresif adalah Valid.

Tabel 5

Uji validitas Pendapatan Wajib Pajak (X2)

\begin{tabular}{|c|c|c|c|}
\hline Item & R hitung & R tabel & Keterangan \\
\hline 1 & 0.416 & 0.235 & Valid \\
2 & 0.299 & 0.235 & Valid \\
3 & 0.401 & 0.235 & Valid \\
4 & 0.247 & 0.235 & Valid \\
5 & 0.357 & 0.235 & Valid \\
6 & 0.484 & 0.235 & Valid \\
\hline
\end{tabular}

Sumber : Data Diolah

Nilai $r$ tabel untuk sampel taraf signifikasi 0.05 ialah 0.235 . Tabel 5 menunjukan bahwa semua butiran pertanyaan mengenai Pendapatan Wajib Pajak (1-6) ialah valid. Karena nilai $r$ hitung lebih besar dari $r$ tabel. Dengan demikian semua butir pertanyaan angkket tranparasi Pendapatan Wajib Pajak ialah valid.

Tabel 6

Uji validasi Daya Beli Komsumen (Y)

\begin{tabular}{|c|c|c|c|}
\hline Item & R hitung & R tabel & Keterangan \\
\hline 1 & 0.418 & 0.235 & Valid \\
2 & 0.355 & 0.235 & Valid \\
3 & 0.338 & 0.235 & Valid \\
4 & 0.362 & 0.235 & Valid \\
5 & 0.485 & 0.235 & Valid \\
\hline
\end{tabular}

Sumber : Data Diolah

Nilai $\mathrm{r}$ tabel untuk sampel taraf signifikasi 0.05 ialah 0.235.Tabel 6 menunjukan bahwasemua butir pertanyaan tentang Daya Beli Konsumen (1-5) adalah valid. Karena nilai $r$ hitung lebih besar dari rtabel. Dengan demikian semua butir pertanyaan angket transparasi Daya Beli Konsumen ialah Valid.

Uji reabilitas (keandalan merupakan ukuran suatu kestabilan dan konsitensi responden dalam menjawab hal yang berkaitan dengan kontruk-kontruk pertanyaan yang merupakan dimensi suatu variabel dan disusun dalam suatu bentuk kuisioner.

\section{Tabel 7}

\section{Uji Reliabel}

\begin{tabular}{|l|l|l|}
\hline Variabel & Cronbach'Alpha & Keterangan \\
\hline PKB Tarif Progresif & 0.760 & Reliabel \\
Pendapatan WP & 0.655 & Reliabel \\
Daya Beli Konsumen & 0.477 & Reliabel \\
\hline
\end{tabular}

Sumber : Data Diolah 
Hasil pengujian reabilitas terhadap semua variabel dengan Cronbach's Alpha dapat dilihat pada tabel 7. Menunjukan nilai Alpha lebih dari $0.6 \%$ oleh karena itu dapat di tentukan bahwa semua instrumen penelitian ini adalah reliabel.

\subsection{Uji Asumsi Klasik}

Pengujian normalitas dilakukan untuk mengetahui apakah dalam suatu regresi (variabel dependen atau variabel independen taupun keduanya) berdistribusi normal atau tidak Ghozali(2016). Uji normalitas data penelitian ini menggunakan metode Kolmogorov-Smirnov. Apabila nilai Asymp. Sig (2-tailed) penelitian ini lebih tinggi dari pada level of significant yaitu 5\% (0.05) maka distribusi normal. Dapat di lihat pada tabel 8.

Tabel 8

Uji Normalitas

\begin{tabular}{|c|c|c|c|}
\hline Variabel & $\begin{array}{c}\text { Kolmogrov- } \\
\text { Smirnov }\end{array}$ & P-Value & Keterangan \\
\hline $\begin{array}{c}\text { Unstandardized } \\
\text { Residual }\end{array}$ & $\mathbf{0 . 8 3 4}$ & 0.490 & $\begin{array}{c}\text { Sebaran data } \\
\text { normal }\end{array}$ \\
\hline
\end{tabular}

Sumber : Data Diolah

Dari hasil uji normalitas menggunakan metode kolmogrov-Smirnov didapatkan hasil signifikan dari uji normalitas sebesar 0.834 .

Peneitian ini untuk menguji adanya multikolinearitasdilihat dari VIF (Variance Inflation Factor) atau nilai tolerance. Menurut Ghozali (2016), bahwa multikolineritas terjadi apabila nilai VIF > 10 atau tolerance value $<0.10$. hasil perhitungan VIF untuk masing-masing variabel bebas disajikan dalam tabel dibawah ini.

\section{Tabel 9}

\section{Uji Multikolinearitas}

\begin{tabular}{|c|c|c|c|}
\hline Variabel & Tolerance & VIP & Keterangan \\
\hline X1 & 0.951 & 1.052 & Bebas Multikoleniaritas \\
X2 & 0.951 & 1.052 & Bebas Multikoleniaritas \\
\hline
\end{tabular}

Sumber : Data Diolah

Dari tabel 9 menujukan bahwa masing-masing nilai VIP berada sekitar 1 sampai 10, demikian juga hasil nilai tolerance mendekati 1 atau diatas 0,1 . Dengan demikian dapat dinyatakan juga model regresi ini tidak terdapat masalah multikolinearitas.

Uji heteroskedastisitas memiliki tujuan untuk mengetahui suatu model regresi apakah terjadi ketidaksamaan variansdari risidual pengamatan satu ke yang lain. Model regresi dapat dikatakan bebas dari heteroskedasitas apabila nilai signifikansi menunjukkan diatas 0,05. Hasil uji heteroskedastisitas disajikan pada Tabel 10 berikut:

Tabel 10

Heteroskedastisitas

\begin{tabular}{|c|c|c|}
\hline Variabel & $P$-Value & Keterangan \\
\hline $\mathrm{X} 1$ & 0.058 & Bebas Heteroskedastisitas \\
$\mathrm{X} 2$ & 0.335 & Bebas Heteroskedastisitas \\
\hline
\end{tabular}

Sumber : Data Diolah 
Berdasarkan hasil yang ditunjukan dalam tabel 10 tersebut nampakbahwa semua variabel bebas menunjukan nilai $\mathrm{P}$ lebih besar dari 0.05 , sehingga dapat disimpulkan bahwa semua variavel bebas tersebut bebas dari masalah heteroskedastisitas.

\subsection{Hasil Analisis Linear Berganda}

Analisis linier berganda digunakan untuk mengetahui besarnya pengaruh Pajak Kendaraan Bermotor tarif Progresif (mobil) (X1) dan Pendapatan Wajib Pajak (X2) terhadap Daya Beli Konsumen kendaraan bermotor roda empat milik pribadi (Y). Hasil analisis regresi dapat dilihat pada tabel 11 yaitu :

\section{Tabel 11}

Uji Analisis Linear Berganda

\begin{tabular}{|c|c|c|c|}
\hline Variabel & Koef. Regresi & "t" hitung & Sig \\
\hline Konstanta & 22.374 & 5.914 & 000 \\
\hline X1 & 0.221 & 1.927 & 058 \\
X2 & -0.125 & -927 & 335 \\
\hline
\end{tabular}

Sumber : Data Diolah

$$
\mathrm{Y}=22.374+0.221+0.125
$$

Untuk menginterpretasi hasil dari analisis tersebut dapat dijelaskan sebagai berikut :

Nilai konstanta sebesar 22.374, menyatakan bahwa jika nilai pajak Kendaraan Bermotor dengan Progresif (mobil) (X1) dan Pendapatan Wajib Pajak (X2) sama dengan nol, maka nilai Daya Beli Konsumen (Y) sebesar 22.374 satuan.

Nilai koefisien (X1) sebesar 0.221. Nilai koefisien yang positif menunjukan bahwa apabila nilai Pajak Kendaraan Bermotor Tarif Progresif menurun maka Daya Beli Konsumen (Y) meningkat sebesar 0.221. satuan dengan asumsi variabel lainnya sama dengan nol

Nilai koefisien (X2) sebesar - 0.125. Nilai koefisien yang negatif menunjukan bahwa apabila nilai Pendapatan Wajib Pajak menurun maka Daya Beli Konsumen menurun sebesar - 0.125.

\subsection{Hasil Pengujian Hipotesis}

Uji Derterminasi merupakan suatu ukuran yang penting dalam regresi. Karena dapat menginfokan baik atau tidaknya model regresi yang terestimasi dengan data sesungguhnya. Nilai koefisien determinasi ini mencerminkan seberapa besar variasi dan variabel terikat $\mathrm{Y}$ dapat dijelaskan oleh variabel bebas $\mathrm{X}$. Bila koefisien determinasi sama dengan $(\mathrm{nol})\left(\mathrm{R}^{2}=0\right)$, artinya variasi dari $\mathrm{Y}$ tidak dapat dijelaskan oleh $\mathrm{X}$ sama sekali. Sementara bila $\mathrm{R}^{2}=1$, maka semua titik pengamatan berada tepat pada garis regresi. Ditentukan oleh $\mathrm{R}^{2}$ nya yang mempunyai nilai antara nol dan satu. Hasil uji koefisen determinasi dapat dilihat pada tabel 12 berikut ini.

Tabel 12

Determinasi $\mathbf{R}^{2}$

Model Summary ${ }^{\mathrm{b}}$

\begin{tabular}{|l|r|r|r|r|}
\hline Model & $\mathrm{R}$ & $R$ Square & $\begin{array}{c}\text { Adjusted } R \\
\text { Square }\end{array}$ & $\begin{array}{c}\text { Std. Error of } \\
\text { the Estimate }\end{array}$ \\
\hline 1 &, $238^{\mathrm{a}}$ &, 057 &, 028 & 1,14729 \\
\hline
\end{tabular}

b. Dependent Variable: TOTAL_Y1

Sumber : Data diolah 
Berdasarkan tabel 12 terlihat pada model summary besarnya nilai $\mathrm{R}^{2}$ yaitu 0,057 dilihat pada kolom $R$ Square. Hal ini berarti bahwa kemampuan variabel independen (PKB Tarif Progresif, Pendapatan Wajib Pajak, Daya Beli Konsumen ) dalam menjelaskan variabel dependen sebesar 0,057 yang berarti $5,7 \%$ sedangkan sisanya $(100 \%-5,7 \%)=94,3 \%)$ dijelaskan oleh variabel-variabel lain diluar model.

Uji statistik digunakan untuk mengetahui ada tidaknya pengaruh variabel independen secara individual (Parsial) terhadap variabel dependen. Hasil uji t dapat dilihat pada tabel 13 berikut.

Tabel 13

Hasil Uji t

Coefficients $^{\mathrm{a}}$

\begin{tabular}{|c|c|c|c|c|c|c|}
\hline & \multicolumn{2}{|c|}{$\begin{array}{l}\text { Unstandardized } \\
\text { Coefficients }\end{array}$} & $\begin{array}{c}\text { Standardized } \\
\text { Coefficients }\end{array}$ & \multirow[t]{2}{*}{$t$} & \multirow[t]{2}{*}{ Sig. } \\
\hline & & $\mathrm{B}$ & Std. Error & Beta & & \\
\hline \multirow{3}{*}{1} & (Constant) & 22,374 & 3,783 & & 5,914 &, 000 \\
\hline & TOTAL_X1 & ,221 & ,115 & ,235 & 1,927 & ,058 \\
\hline & TOTAL_X2 &,- 125 & ,128 &,- 118 &,- 972 & ,335 \\
\hline
\end{tabular}

a. Dependent Variable: TOTAL_Y1

\section{Sumber : Data diolah}

Berdasarkan hasil pengujian t pada tabel 13 menunjukan dari kedua variabel yang di masukan kedalam model regresi, terlihat bahwa variabel Pajak Kendaraan Bermotor Tarif Progresif (mobil), nilai t hitung < t tabel sebesar 1,927 < 1996 dan signifikan lebih besar dari 0,05 yaitu 0,058 > 0,05 maka dapat dikatakan tidak berpengaruh signifikan terhadap Daya

Beli Konsumen. Sedangkan variabel Pendapatan Wajib Pajak memiliki nilai $t$ hitung $<\mathrm{t}$ tabel sebesar $-927<1996$ dan signifikan lebih besar dari 0,05 yaitu 0,335>0,05 maka dapat dikatakan tidak berpengaruh terhadap Daya Beli Konsumen

Dengan ini melihat unstandardized coefficient dapat disimpulkan persamaan berikut :

$\mathrm{Y}=\mathbf{2 2 , 3 7 4}+\mathbf{0 , 2 2 1}+\mathbf{0 , 1 2 5}+\mathrm{e}$

Uji $\mathrm{F}$ atau dikenal dengan uji serntak atau uji model Anova bertujuan untuk melihat bagaimanakah pengaruh semua variabel bebasnya bersama-sama terhadap variabel terikatnya.

Tabel 14

Uji F

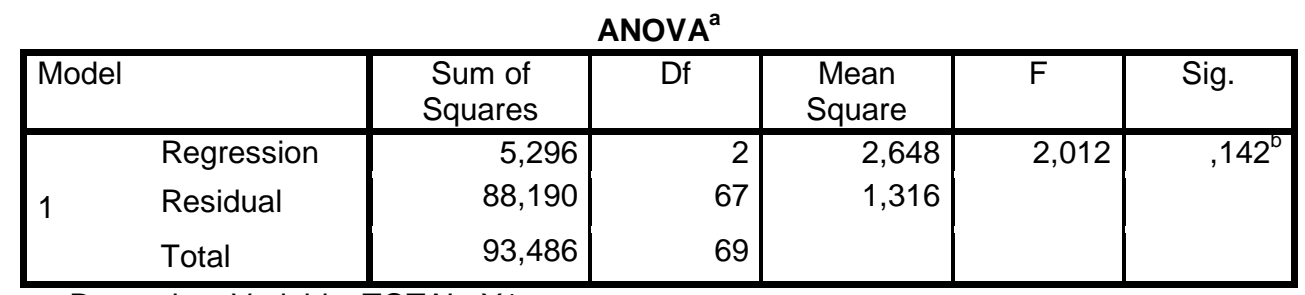

a. Dependent Variable: TOTAL_Y1

b. Predictors: (Constant), TOTAL_X2, TOTAL_X1

Sumber : Data diolah

Berdasarkan tabel 14 diketahui hasil Uji F menunjukan bahwa $\mathrm{F}$ hitung sebesar 2,012 dengan tingkat signifikan sebesar 0,14. Karena signifikan $F$ hitung lebih besar dari 0,05 sehingga dapat disimpulkan bahwa model regresi yang digunakan untuk menguji variabel independen terhadap variabel dependen layak digunakan. 


\subsection{Pembahasan}

\section{H1 : Pajak Kendaraan Bermotor Tarif Progresif terdahap Daya Beli Kosumen}

Hasil regresi yang ditunjukan pada tabel 4:18 diperoleh hasil koefisien regresi untuk variabel Pajak Kendaraan Bermotor Tarif Progresif di peroleh t hitung sebesar 1,927 dengan signifikan sebesar 0,058 karena nilai signifikan sebesar 0,058 lebih besar dari 0,05 dan nilai t hitung 1,927 lebih kecil dari t tabel 1,996 sehingga dapat di simpulkan bahwa hipotesis pertama (H1) : Pajak Kendaraan Bermotor tarif Progresif terhadap Daya Beli Konsumen, ditolak.

Dengan demikian penelitian ini menyatakan Pajak Kendaraan Bermotor Tarif Progresif (mobil ) tidak pengaruh positif signifikan terhadap daya beli konsumen kendaraan bermotor roda empat. Sebab kurang adanya sosialisasi tarif progresif kepada wajib pajak, sehingga meningkat tarif progresif apabila kendaraan bermotor yang digunakan semakin besar.

Melalui analisis regresi yang digunakan, diperoleh hasil yang mendukung hipotesis bahwa semakin rendah pajak kendaraan bermotor tarif progresif yang dikenakan, maka daya beli akan semakin meningkat.

Pajak kendaraan bermotor tarif progresif akan berpengaruh pada daya beli konsumen. Tarif pajak kendaraan bermotor yang menurun mengikuti dengan kepemilikan kendaraan bermotor yang akan menyebabkan konsumen harus membayar pajak kendaraan bermotor lebih tinggi untuk kepemilikan kedua dan seterusnya. Sehingga konsumen akan merasa tidak terbeban dengan tarif pajak yang menurun dan akan menambah pembelian terhadap kendaraan bermotor roda empat. Penelitian ini mengacu pada pada beberapa penelitian sebelumnya.

Hal ini sama dengan yang diteliti oleh Indirayuti (2019) mengatakan bahwa pajak kendaraan bermotor tarif progresif tidak berpengaruh signifikan. Pengujian yang diteliti oleh Murthi, Buhdi, \& Purbadharmaja(2015)mengatakan pengenaan Pajak Kendaraan Bermotor dengan tarif progresif mempunyai pengaruh positif terhadap daya beli masyarakat. dilakukan oleh Ridwan(2012)menunjukan bahwa pendapatan berpengaruh positif terhadap daya beli. Diperkuat dengan penelitian yang dilakukan oleh Chaerannisah(2014) dan Hetriana (2015) yang menyatakan pendapatan berpengaruh positif signifikan terhadap daya beli dilakukan oleh Ridwan(2012)menunjukan bahwa pendapatan berpengaruh positif terhadap daya beli. Diperkuat dengan penelitian yang dilakukan oleh Chaerannisah(2014) dan Hetriana (2015) yang menyatakan pendapatan berpengaruh positif signifikan terhadap daya beli.

Namun, hasil pengujian yang diteliti olehAdiputri \& Jati(2018) Pengaruh PKB Tarif Progresif dan Pendapatan Wajib Pajak Terhadap Daya Beli Kendaraan Bermotor Roda Empat. Hasil penelitian tersebut menunjukan bahwa pajak kendaraan bermotor tarif progresif berpengaruh negatif terhadap daya beli konsumen kendaraan bermotor roda empat milik pribadi, Ratnasari \& Setiawan(2016) dan Devi (2017)mengenai pengenaan Pajak Kendaraan Bermotor terhadap daya beli konsumen memperlihatkan hasil ialah Pajak Kendaraan Bermotor mempunyai pengaruh negatif pada daya beli konsumen. Peningkatnya beban pajak akan menurunkan daya beli konsumen Ratnasari(2015). Pengenaan tarif progresif dalam Pajak Kendaraan Bermotor akan mengakibatkan pemilik kendaraan terkena terkena pajak lebih tinggi untuk pembayaran pajak pajak kendaraan kedua dan selanjutnya sehingga da beli masyarakat pada kendaraan bermotor akan menurun, terutama kendaraan bermotor roda empat Ermawati \& Widiastuti(2014).

Penelitian sebelumnya yang dilakukan oleh Ridwan(2012)menunjukan bahwa pendapatan berpengaruh positif terhadap daya beli. Diperkuat dengan penelitian yang dilakukan oleh Chaerannisah(2014) dan Hetriana (2015) yang menyatakan pendapatan berpengaruh positif signifikan terhadap daya beli. 


\section{H2 : Pendapatan Wajib Pajak Terhadap Daya Beli Konsumen}

Hasil regresi yang ditunjukan pada tabel 4:18 diperoleh hasil koefisien regresi untuk variabel Pendapatan Wajib Pajak di peroleh t hitung sebesar -972 dengan signifikan sebesar 0,335 karena nilai signifikan sebesar 0,335 lebih besar dari 0,05 dan nilai t hitung -927 lebih kecil dari t tabel 1,996 sehingga dapat di simpulkan bahwa hipotesis pertama (H2) : Pendapatan Wajib Pajak terhadap

\section{Daya Beli Konsumen, ditolak.}

Dengan demikian Hipotesis kedua dalam penelitian ini menyatakan bahwa pendapatan wajib pajak tidak berpengaruh negatif terhadap daya beli konsumen kendaraan bermotor roda empat. Melalui analisi regresi yang digunakan,diperoleh hasil yang mendukung hipotesis bahwa semakin kurang pendapatan seorang wajib pajak, maka daya beli akan semakin menurun. Dalam hal ini daya beli kendaraan bermotor roda empat. Hasil penelitian ini mendukung teori ekonomi dimana semakin rendah rendah pendapatan seorang wajib pajak, maka daya beli akan semakin menurun. Akan berbeda dengan Penelitian sebelumnya yang dilakukan Adiputri \& Jati(2018) Pengaruh pendapatan wajib berpengaruh positif terhadapat daya beli kendaraan bermotor roda empat milik pribadi serta dilakukan oleh Ridwan (2012) menunjukan bahwa pendapatan berpengaruh positif terhadap daya beli. Kemudian penelitian yang dilakukan oleh Chaerannisah (2014) dan Hetriana (2015) yang menyatakan pendapatan berpengaruh positif signifikan terhadap daya beli konsumen.

\section{PENUTUP}

\subsection{Kesimpulan}

Berdasarkan hasil analisis dan pengujian hipotesis dapat di buat kesimpulan sebagai berikut :

Hasil penelitian ini menunjukan bahwa Pajak Kendaraan Bermotor tarif progresif tidak berpengaruh positif signifikan terhadap daya beli konsumen kendaraan bermotor roda empat milik pribadi di Kota Jayapura. Artinya semakin rendah pajak kendaraan bermotor tarif progresif yang dikenakan pada kendaraan roda empat, maka daya beli konsumen kendaraan bermotor roda empat milik pribadi semakin meningkat.

Hasil penelitian ini juga menunjukan bahwa Pendapatan wajib pajak tidak berpengaruh negatif signifikan terhadap daya beli konsumen kendaraan bermotor roda empat milik pribadi di Kota Jayapura. Artinya semakin rendah pendapatan, maka daya beli konsumen kendaraan bermotor roda empat milik pribadi di Kota Jayapura semakin menurun.

\subsection{Saran}

Saran ini bertujuan untuk memberikan masukan kepada peneliti selanjutnya ataupun untuk akademis agar dapat mengisi kekurangan yang terdapat pada penelitian sebelumnya. Adapun sarab dari peneliti yaitu sebagai berikut :

Diharapkan Peneliti selanjutnya dapat menggunakan sampel yang lebih luas. dan juga dapat mengeksplorasi faktor-faktor lain selain pajak kendaraan bermotor tarif progresif seperti penghindaraan pajak progresif sehingga mempengaruhi proses daya beli konsumen kendaraan bermotor roda empat milik pribadi.

Penelitian selanjutnya mampu memperluas tempat penelitian dan dapat juga menambahkan variabel moderasi atau variabel bebas lainnya. 


\section{DAFTAR PUSTAKA}

Adiputri, N. K. A. G. S., \& Jati, I. K. (2018). Pengaruh PKB Tarif Progresif dan Pendapatan WP Terhadap Daya Beli Konsumen Kendaraan Bermotor Roda Empat. E-Jurnal Akuntansi Universitas Udayana, 24, 1632-1657. Retrieved from doi: https://doi.org/10.24843/EJA.2018.v24.i02.p30

Chaerannisah. (2014). Analisis Faktor-Faktor Yang Mempengaruhi Permintaan Mobil Di Kota Makassar. http://repository.unhas.ac.id/handle/123456789/9506

Claudya. (2015). Analisis Pengaruh Pajak Pertambahan Nilai ( PPN ) Dan Pajak Penjualan Atas Barang Mewah ( Ppnbm ) Kendaraan Bermotor. 15(05), 132-143. Retrieved from https://ejournal.unsrat.ac.id/index.php/jbie/article/view/9730

Danil, M. (2013). Pengaruh Pendapatan Terhadap Tingkat Konsumsi pada Pegawai Negeri Sipil di Kantor Bupati Kabupaten Bireuen. STIE Kebangsaan Bireuen, Aceh. Retrieved from https://www.scribd.com/document/348220553/140412594

Devi, S. A. P. P. (2017). Pengaruh Pajak Pertambahan Nilai, Pajak Penjualan Atas Barang Mewah dan Pajak Kendaraan Bermotor Tarif Progresif Terhadap Daya Beli Konsumen Kendaraan di Denpasar. 18(2017), 674-704. $\quad$ Retrieved from https://ojs.unud.ac.id/index.php/Akuntansi/article/view/25424/16974

Ermawati, E., \& Widiastuti, N. P. E. (2014). Dampak Pengenaan Tarif Pajak Progresif Kendaraan Bermotor Di Propinsi Dki Jakarta. Infestasi, 10, 103-114. https://doi.org/10.21107/infestasi.v10i2.529

Fadillah, R., \& Kiswara, E. (2012). Pengaruh pengenaan pajak pertambahan nilai dan cukai rokok terhadap skema finansial produk rokok. 1, 1-12. Retrieved from http://eprints.radenfatah.ac.id/415/1/

Ghozali, I. (2016). Prof (p. 160). p. 160.undip.ac.id

Hetriana, T. (2015). Perilaku Konsumsi Sepeda Motor Dalam Perspektif Ekonomi Islam ( Studi Kasus Daerah Tanjung Enim ) Skripsi Diajukan Kepada Fakultas Ekonomi Dan Bisnis Islam Uin Raden Fatah Untuk Memenuhi Salah Satu Syarat Guna Memperoleh Gelar Sarjana Ekonomi Syariah ( S . http://eprints.radenfatah.ac.id/415/.

Husein, U. (2008). Metode Penelitian Untuk Skripsi dan Tesis Bisnis. Jakarta: PT.Raja Grafindo Persada.http://scholar.google.co.id/citations?user=dyxe6w8aaaaj\&hl=id.

Imtikhanah dan Susiltoyowati, 2010. (2010). IPI Pengaruh Faktor-Faktor Dalam Diri Wajib Pajak Terhadap Penerimaan Pajak PBB di Kabupaten Pekalongan _ View articlei. Retrieved from http://id.portalgaruda.org/index.php?Ref=browse \&mod=viewarticle \&article $=200490$

Indirayuti, A. (2019). PENGARUH PPN DAN PKB TARIF PROGRESIF TERHADAP DAYA BELI KONSUMEN ( Studi Empiris Pada Konsumen Kendaraan Roda Empat di Yogyakarta ). 1(1), 1322. https://doi.org/10.24964/japd.v1i1.839

Irwanto, R. (2015). Analisis Penerapan Pajak Progresif Terhadap Wajib Pajak Kendaraan Bermotor (Studi Kasus SAMSAT Kota Makassar). Skripsi Fakultas Ekonomi Dan Bisnis Universitas Hasanuddin Makassar. Retrieved from https://docplayer.info/41140486

Lapodo, N., \& Sulaeman. (2016). Analisis Pendapatan dan Kelayakan Usahatani Padi Sawah di Desa Sidera Kecamatan Sigi Biromaru Kabupaten Sigi. Jurnal Agroland, 23(1), 64-69. Retrieved from http://jurnal.untad.ac.id/jurnal/index.php/AGROLAND/article/view/8116/6432

Mardiasmo. (2011). Perpajakan Edisi Revisi 2011. Retrieved from https://www.bukupedia.com/id/book/id-38-55297/pengembangan-diri-motivasi/perpajakan-edisirevisi-2011.html

Mariska febe. (2015). Analisis Pengaruh Pengenaan Pajak Pertambahan Nilai (PPN) dna Pajak Penjualan Atas Barang Mewah (ppnbm) Terhadap Daya Beli Konsumen Pada Barang Elektronika (Studi Empiris pada Konsumen Barang Elektronika. Retrieved from https://www.academia.edu/11350639/

Murthi, N. W., Buhdi, M. K. S., \& Purbadharmaja, I. B. (2015). Pengaruh Pajak Progresif Terhadap Perilaku Konsumtif, Basis Pajak, Kepatuhan Wajib Pajak Dan Pendapatan Daerah Provinsi Bali. Jurnal Ekonomi Dan Bisnis Universitas Udayana, 12(4), 1001- 
1028. https://ojs.unud.ac.id/index.php/eeb/article/view/16368

Nababan, S. S. M. (2013). Pendapatan dan Jumlah Tanggungan Pengaruhnya Terhadap Pola Konsumsi PNS Dosen dan Tenaga Kependidikan pada Fakultas Ekonomi dan Bisnis Universitas Sam Ratulangi Manado. Jurnal Riset Ekonomi, Manajemen, Bisnis, Dan Akuntansi, 1(4), 2130-2141. Retrieved from https://ejournal.unsrat.ac.id/index.php/emba/article/view/3423/2966

Rahman, A. (2018). Pengaruh Kesadaran Wajib Pajak, Tingkat Pendidikan, dan Pendapatan terhadap Kepatuhan Membayar Pajak Bumi dan Bangunan. 120.http://ejournal.unp.ac.id/students/index.php/akt/article/view/2946.

Ratnasari, I. A. P. (2015). Pengaruh Pajak Pertambahan Nilai dan Pajak Kendaraan Bermotor Tarif Progresif Terhadap Daya Beli Konsumen Kendaraan. 151, 10-17. https://doi.org/10.1145/3132847.3132886

Ratnasari, I. A. P., \& Setiawan, P. E. (2016). Pengaruh Pajak Pertambahan Nilai Dan Pajak Kendaraan Bermotor Tarif Progresif Terhadap Daya Beli Kendaraan Di Denpasar. E-Jurnal Akuntansi Universitas Udayana, 15, 887-914.https://ojs.unud.ac.id/index.php/akuntansi/article/view/15020.

Ridwan, M. (2012). Pengaruh Faktor Sosio-Ekonomi Terhadap Kepemilikan Mobil dan Sepeda Motor di Kota $\quad$ Langsa. $\quad$ Retrieved from www.rp2u.unsyiah.ac.id/index.php/welcome/prosesdownload/402/5

Soediyono Reksoprayitno. (2007). Pengantar Ekonomi Mikro Edisi Millenium. Retrieved from https://www.belbuk.com/pengantar-ekonomi-mikro-edisi-millennium-p-17917.

Syarif, S. M., Dan, N. S. A., \& Junaidi. (2554). Pengaruh Harga Bahan Bakar Minyak dan Perubahan Cuaca

Terhadap

Pendapatan.

$71-$ 89. http://riset.unisma.ac.id/index.php/jra/article/viewfile/391/431

Utami. (2006). Pengaruh Pengenaan Pajak Pertambahan Nilai (PPN)dan Pajak Penjualan Atas Barang Mewah (ppnbm) Terhadap Daya Beli Konsumen Alat Fotografi (Studi Empiris pada Perhimpunan Amatir Foto di Kota Bandung). Retrieved from http://repository.maranatha.edu/id/eprint/19338 